\title{
Animal Models in the Research of Abdominal Aortic Aneurysms Development
}

\author{
N. PATELIS ${ }^{1}$, D. MORIS ${ }^{2}$, D. SCHIZAS ${ }^{1}$, C. DAMASKOS ${ }^{3}$, D. PERREA $^{3}$, \\ C. BAKOYIANNIS ${ }^{1}$, T. LIAKAKOS ${ }^{1}$, S. GEORGOPOULOS ${ }^{1}$
}

${ }^{1}$ First Department of Surgery, Vascular Unit, Laikon General Hospital, Medical School, National and Kapodistrian University of Athens, Greece, ${ }^{2}$ Cleveland Clinic, Lerner Research Institute, Cleveland, OH, USA, ${ }^{3}$ Laboratory for Experimental Surgery and Surgical Research "N. S. Christeas", Medical School, National and Kapodistrian University of Athens, Greece

Received December 23, 2016

Accepted May 2, 2017

On-line September 22, 2017

\section{Summary}

Abdominal aortic aneurysm (AAA) is a prevalent and potentially life threatening disease. Many animal models have been developed to simulate the natural history of the disease or test preclinical endovascular devices and surgical procedures. The aim of this review is to describe different methods of AAA induction in animal models and report on the effectiveness of the methods described in inducing an analogue of a human AAA. The PubMed database was searched for publications with titles containing the following terms "animal" or "animal model(s)" and keywords "research", "aneurysm(s)", "aorta", "pancreatic elastase", "Angiotensin", "AngII" "calcium chloride" or " $\mathrm{CaCl}_{2}$ ". Starting date for this search was set to 2004, since previously bibliography was already covered by the review of Daugherty and Cassis (2004). We focused on animal studies that reported a model of aneurysm development and progression. A number of different approaches of AAA induction in animal models has been developed, used and combined since the first report in the 1960's. Although specific methods are successful in AAA induction in animal models, it is necessary that these methods and their respective results are in line with the pathophysiology and the mechanisms involved in human AAA development. A researcher should know the advantages/disadvantages of each animal model and choose the appropriate model.

\section{Key words}

Abdominal aortic aneurysms • AAA • Animal models $\bullet$ Induction

\section{Corresponding author}

N. Patelis, First Department of Surgery, Vascular Unit, Laikon General Hospital, Medical School, National and Kapodistrian University of Athens, $17 \mathrm{Ag}$. Thoma St, 11527 Athens, Greece. E-mail: patelisn@gmail.com

\section{Introduction}

Abdominal aortic aneurysms (AAAs) represent a potentially fatal disorder that affects around $2 \%$ of the general population, with a peak incidence in the elderly (Ernst 1993, Svensjo et al. 2011, Moris et al. 2014). Despite emerging reports about the changing epidemiology with a much lower prevalence, AAA is the $15^{\text {th }}$ leading cause of mortality in the USA in males 60-64 years old and in the past it has been reported to cause approximately $1 \%$ of all deaths in the developed countries (Schermerhorn and Cronenwett 2001, Center for Disease Control 2014).

AAAs are thought to develop through a combination of multiple genetic and other factors, including age, gender, family history, hypertension and atherosclerosis. Atherosclerosis, as a degenerative disease, has been traditionally associated with AAA, but the underlying pathophysiology of the aortic dilation process is only partially understood (Aoki et al. 2007, Moris et al. 2017). The most significant epidemiologic risk factor known for the development and expansion of 
AAAs is smoking, with smokers demonstrating a three to six-fold increased risk of death from AAA compared to non-smokers (Ernst 1993, Ahluwalia et al. 2007).

Recent research with either human tissue or animal models has led to a shift regarding AAA, and AAA development is now considered to be part of a significant and dynamic remodeling process in the vessel (Longo et al. 2005, Osborne-Pellegrin et al. 1994). The remodeled aortic wall is characterized by the depletion of smooth muscle cells (SMC), chronic medial and adventitial inflammation, elastin degeneration and medial attenuation (Henderson et al. 1999, Rowe et al. 2000, Shimizu et al. 2006).

A number of previous studies have confirmed the role of inflammatory process in AAA, particularly related to an upregulation of matrix metalloproteinases (MMPs), especially MMP-2 and MMP-9 (OsbornePellegrin et al. 1994, Nordon et al. 2009, Thompson et al. 1995). The key-role of MMPs in AAA development is also supported by research results showing that overexpressed recombinant Tissue Inhibitor of Matrix Metalloproteinases (TIMP-1) and synthetic MMP inhibitors inhibit aneurysm growth in a rat model (Allaire et al. 1998a, Bigatel et al. 1999, Holmes et al. 1996). Most parts of the functional regulation of these MMPs and their contribution to Extracellular Matrix (ECM) proteolysis in AAA formation remain unclear and should be clarified by future studies.

Much of the current knowledge on the pathophysiology of AAAs comes from research on affected animal models. These models have gradually been developed over time and the milestones of the development of AAA experimental models are summarized in Table 1. A common animal model for the aneurysmal aortic lesions consists of the transient perfusion of the abdominal aorta with PPE (Pyo et al. 2000). Another common model of AAA induction is $\mathrm{CaCl}_{2}$ perfusion of the aorta (Gertz et al. 1988). Other AAA induction methods are also reported including mechanical induction through aortic stretching, patching or injury; or in some cases a combination of some of the previously mentioned methods (Li et al. 2013, Lin et al. 2013, Mata et al. 2011, Maynar et al. 2003, Czerski et al. 2013).

The aim of this review is to describe different methods of AAA induction in animal models and report on the relevance of the methods described in inducing an analogue of a human AAA.
Table 1. Milestones in the development on animal models in AAA.

\begin{tabular}{|c|c|}
\hline $\begin{array}{l}\text { Author and year } \\
\text { of publication }\end{array}$ & Milestone \\
\hline $\begin{array}{l}\text { Economou et al. } \\
1960\end{array}$ & $\begin{array}{l}\text { Aortic aneurysm experimentatior } \\
\text { in animal models. }\end{array}$ \\
\hline Nabseth et al. 1963 & $\begin{array}{l}\text { PPE induction of AAA animal } \\
\text { models. }\end{array}$ \\
\hline Gertz et al. 1988 & $\mathrm{CaCl}_{2}$ induction of $\mathrm{AAA}$ \\
\hline Anidjar et al. 1990 & $\begin{array}{l}\text { PPE under pressure for AAA } \\
\text { induction. Reduced induction } \\
\text { time to } 2 \mathrm{~h} \text {. }\end{array}$ \\
\hline Tanaka et al. 2009 & $\begin{array}{l}\text { Combined use of } \mathrm{CaCl}_{2} \text { and } \\
\text { PPE for AAA induction. }\end{array}$ \\
\hline
\end{tabular}

Search strategy

The MEDLINE/PubMed database was searched for publications with titles containing the following terms: "animal" or "animal model(s)" and keywords: "research", "aneurysm(s)", "aorta", "pancreatic elastase", "Angiotensin", "AngII" or " $\mathrm{CaCl}_{2}$ ". Two independent reviewers (N. P. and D. M.) performed the literature search, the study selection and the data extraction. All the references from the identified articles were searched for relevant information. The starting date was 2004, since previously bibliography was covered by the review of Daugherty and Cassis (2004) and the end date of the literature search was set to September 2016.

We focused on animal studies that reported a model of aneurysm generation and expansion. We excluded articles that were not written in English or articles which their full-texts and abstracts were not accessible or comprehensive.

\section{Results}

We classified the results of the evaluated studies after 2004 classified based on the approach of aneurysm generation (Table 2).

\section{Porcine pancreatic elastase (PPE) model}

Pyo et al. (2000) induced AAAs via PPE perfusion in mice deficient in MMP-9 and/or MMP-12. This study confirmed the different role of MMP-9 and MMP-12 in the destruction of the medial elastic fibers following initial aortic injury resulting from PPE activity. MMP-12 deficient mice did not sustain a significant 
impact after PPE activity, while MMP-9 deficient mice developed AAA.

A work by Bi et al. (2013a) studied the effect of PPE induction on an aortic section of New Zealand white rabbits. Animals were divided into three study groups (B, C, D) receiving $0.1,5$ and $10 \mathrm{U} / \mu \mathrm{l}$, respectively. Group A received induction of normal saline and acted as control group. Twelve more animals were used as long-term follow-up group after induction with $10 \mathrm{U} / \mu \mathrm{l}$ PPE (group E). Animals of groups $\mathrm{A}$ to $\mathrm{D}$ were gradually sacrificed on $15-150^{\text {th }}$ postoperative day (POD). In this study, only groups $\mathrm{C}$ and $\mathrm{D}$ developed aneurysms. The inner aortic diameter in group $\mathrm{D}$ dilated significantly when compared to groups $\mathrm{A}$ and $\mathrm{C}$ from day 0 to day 5 $(p<0.0001$ and $p<0.05$, respectively). Outer diameter in group D increased significantly compared to group A and group B from $15 \mathrm{~min}$ to 5 days $(\mathrm{p}<0.01$ and $\mathrm{p}<0.05$, respectively). On day 5 after surgery, rabbits in group $\mathrm{E}$ showed significant dilation of the aortic diameter, which remained stable over 100 days, followed by a later decrease in diameter. The intima-media thickness (IMT) tended to increase in group $\mathrm{C}$ when compared to group $\mathrm{A}$ $(p<0.0001)$, while there was a significant decrease in IMT between group A and group D $(\mathrm{p}<0.01)$. In group $\mathrm{E}$, there was an obvious tendency towards higher IMT on day 150 when compared to groups A or D on day 5 ( $p<0.0001$ for both). In group E, an increase in IMT was observed starting at day 15 after surgery and gradually increased by day $40(\mathrm{p}<0.01)$ and day $150(\mathrm{p}<0.0001)$ when compared to group $\mathrm{D}$ on day 5 with the degree of intimal hyperplasia being assessed by the intima/media ratio day 40 $(0.61 \pm 0.27, \mathrm{p}<0.01)$ and day $150(1.67 \pm 0.81, \mathrm{p}<0.0001)$ compared to group $\mathrm{D}$ on day $5 \quad(0.12 \pm 0.1)$. In groups B, C and D, the aortic wall became disorganized and the elastic externa and lamellae in the media were fragmented. A large amount of red blood cells and inflammatory cells were present in the media of group D, and the elastin fibers were scarce. Elastin content decreased significantly in all groups apart from group E, in which it increased significantly $(\mathrm{p}<0.0001)$. PPE induction did not seem to lead to collagen reduction, but collagen concentration increased significantly in group $\mathrm{E}$ by day 40 $(\mathrm{p}<0.01)$. MMP-2 expression was increased in all PPE-induced segments. Only the expression in group D was significant compared to group A on day $5(\mathrm{p}<0.01)$. Five days after surgery, expression of MMP-9 was present in all PPE-treated groups, while no expression was observed in the group A. On day 5, an obvious tendency of SMC loss with increased PPE concentrations was reported.
SMC in all PPE-induced sections decreased significantly compared to group A $(\mathrm{p}<0.01)$. SMC regenerated significantly in group E 15 days after surgery when compared to day $5(\mathrm{p}<0.0001)$ and almost returned to normal numbers after 5 months (Bi et al. 2013a).

Bhamidipati et al. (2012) performed a study where a group of mice received intraoperative aortic infusion of PPE. A subgroup of these mice also received doxycycline peroral. Aortas were harvested on day 14. Mice subjected to PPE infusion had an $82 \pm 15 \%$ increase in aortic size with $60 \%$ incidence compared to $20 \pm 3 \%$ for the control group. Additionally, mice subjected to PPE infusion and peroral administration of doxycycline showed a statistically significant difference in the aortic diameter growth when compared to those subjected only to PPE infusion $(37 \pm 10 \%$; $=0.03)$.

In the same year, another publication (Molacek et al. 2009), suggested a different approach to AAA induction, this time using pigs as a model. Pigs were divided into three groups undergoing a different AAA induction technique. One group was subjected to intraluminal PPE infusion, the second group received saline aortic infusion and the third group of animals received a patch sealing over the aortotomy site. All groups received a stenotic cuff placed under the renal arteries. A fourth group did not undergo any manipulation and acted as the control group. Aortic dilation was significant only when the first group and the control group were compared $(p<0.0156)$. Signs of medial inflammation and elastic lamellae destruction were also observed in the first group.

Zhou et al. (2013), studied the effect of type 1 PPE under pressure of $100 \mathrm{~mm} \mathrm{Hg}$ on the aortic wall of $\mathrm{CD} 43^{-/}$mice, as well to wild-type (WT) mice. On the 14th POD, the diameter of the affected aortic section was measured in situ and it was reported that the absence of CD43 protected mice from aneurysm development when compared to WT mice (aortic diameter increase $91.8 \pm 6.2 \%$ vs. $144.8 \pm 3.7 \%$, in $\mathrm{CD} 43^{-/-}$animals and WT animals respectively; $\mathrm{p}<0.0001)$. Histologic analysis of the excised aortas revealed significant fragmentation of the elastic fibers and depletion of SMC actin in WT mice compared with the relatively well-preserved elastic lamellae and SMC actin content in $\mathrm{CD} 43^{-/-}$mice $(p<0.0001)$. Despite the role of CD43 in immune response being difficult to clearly establish, this study reported significantly less Mac-3+ macrophages $(\mathrm{p}<0.0001), \mathrm{CD} 8+\mathrm{T}$ cells and CD3 $+\mathrm{T}$ cells $(\mathrm{p}<0.0001)$ in $\mathrm{CD} 43^{-/-}$mice, abrogating aneurysm development by 


\begin{tabular}{|c|c|c|c|c|c|c|c|c|c|c|c|}
\hline 象 & 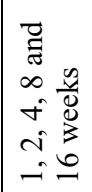 & 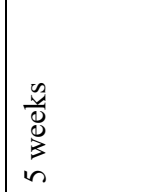 & 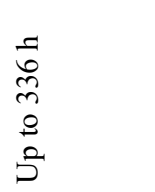 & 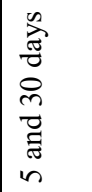 & $\frac{\tilde{z}}{\mathrm{z}}$ & $\frac{\tilde{z}}{\mathrm{z}}$ & 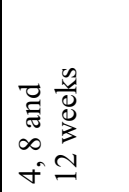 & 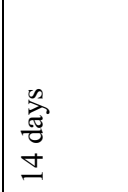 & $\begin{array}{l}\text { a } \\
\text { d } \\
0 \\
0 \\
0 \\
0 \\
0 \\
5\end{array}$ & 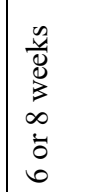 & 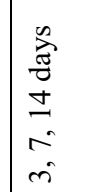 \\
\hline 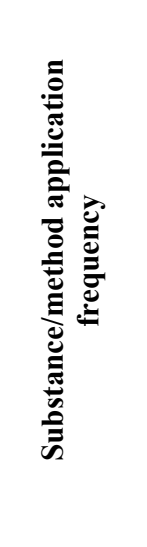 & 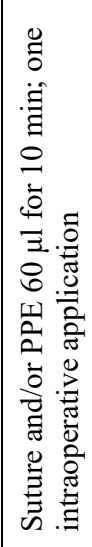 & 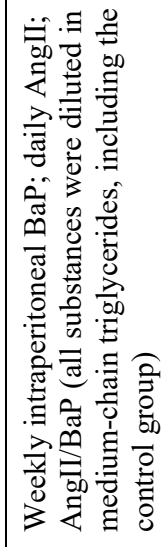 & 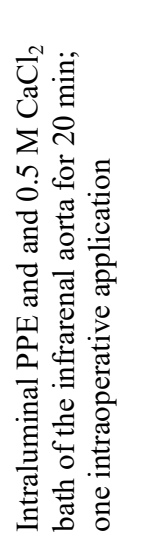 & 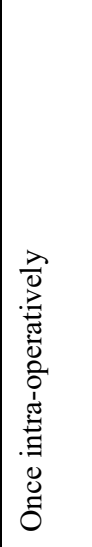 & 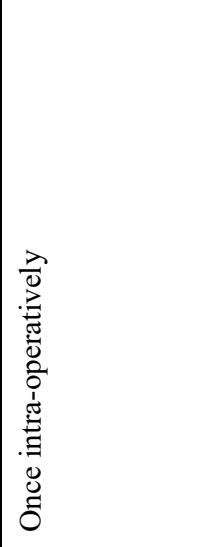 & 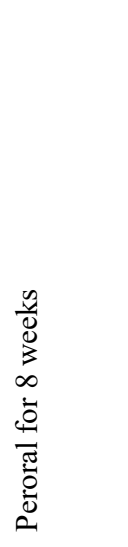 & 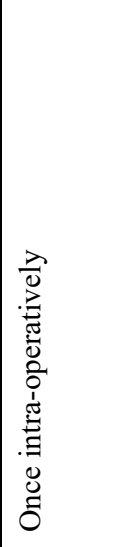 & 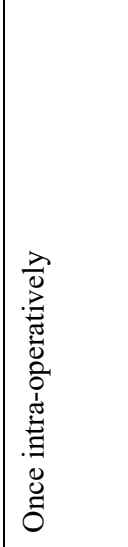 & 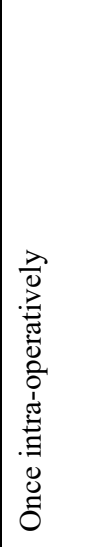 & 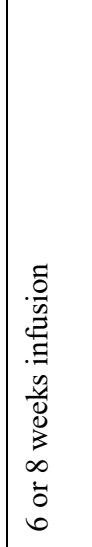 & 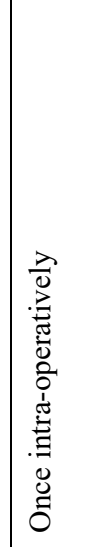 \\
\hline 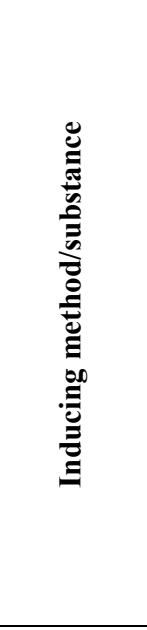 & 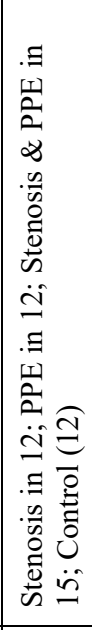 & 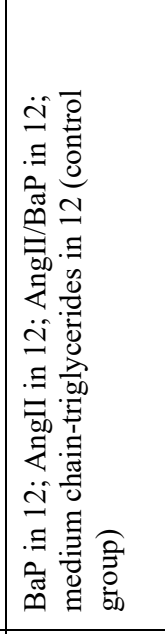 & 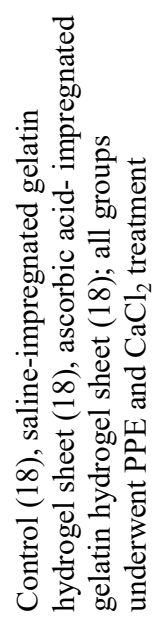 & 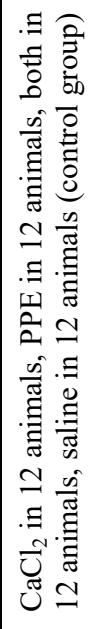 & 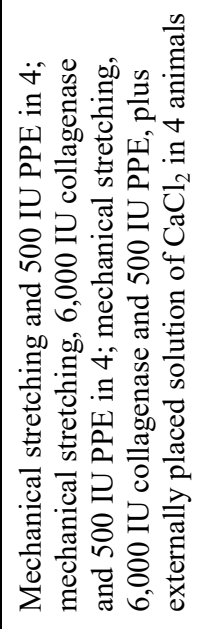 & 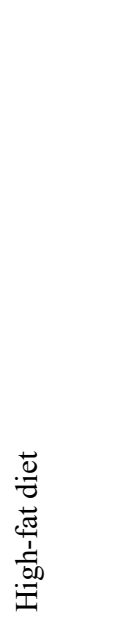 & 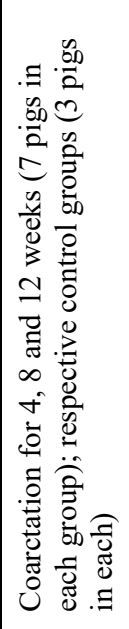 & 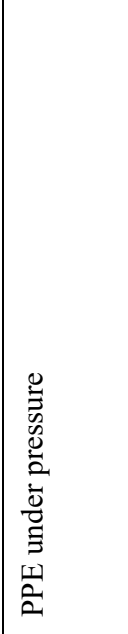 & 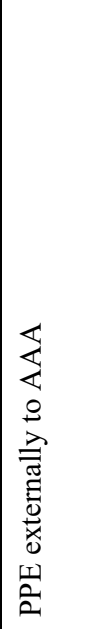 & 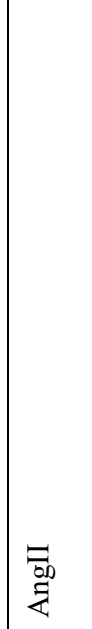 & 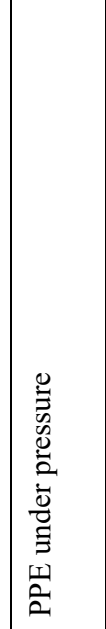 \\
\hline 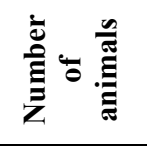 & $\bar{n}$ & $\stackrel{\infty}{q}$ & in & $\stackrel{\infty}{q}$ & $\simeq$ & $\tilde{z}$ & in & $\tilde{z}$ & İ & $\frac{\tilde{z}}{z}$ & $\tilde{z}$ \\
\hline 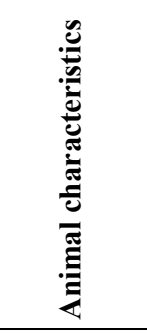 & $\frac{0}{\tilde{m}_{\mathrm{z}}^{2}}$ & 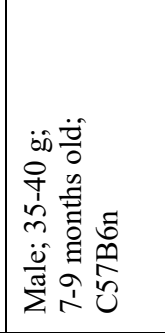 & 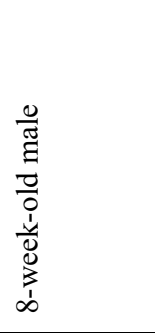 & 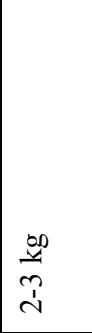 & 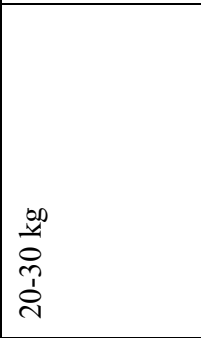 & 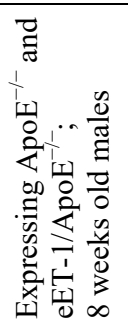 & 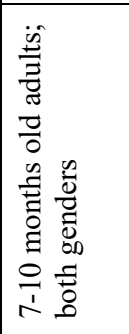 & 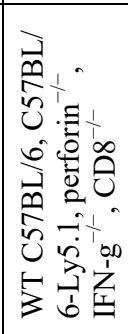 & 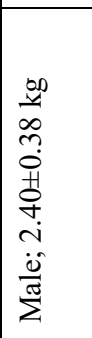 & 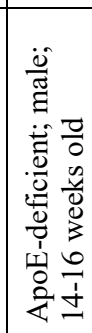 & 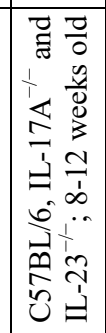 \\
\hline 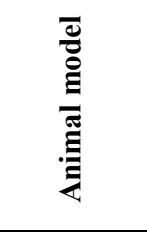 & 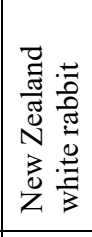 & 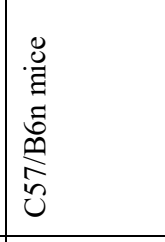 & 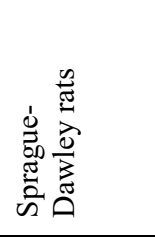 & 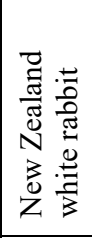 & $\frac{\frac{9}{0}}{\frac{\partial}{50}}$ & $\frac{\mathscr{g}}{\Sigma}$ & 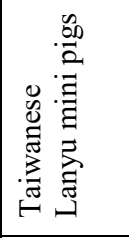 & $\stackrel{8}{\frac{8}{2}}$ & 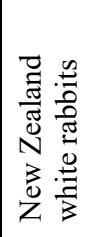 & $\stackrel{\mathscr{g}}{\Sigma}$ & $\stackrel{\mathscr{g}}{\Sigma}$ \\
\hline 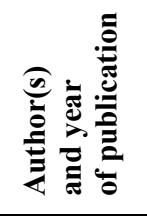 & 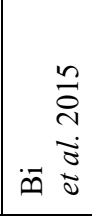 & 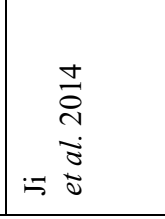 & 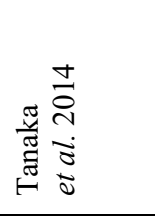 & 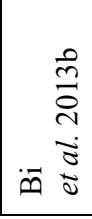 & 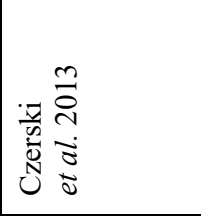 & 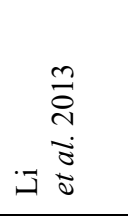 & 离 & 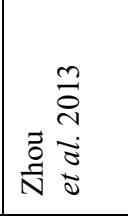 & 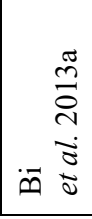 & 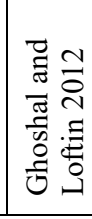 & 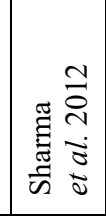 \\
\hline
\end{tabular}




\begin{tabular}{|c|c|c|c|c|c|c|c|c|c|}
\hline $\begin{array}{l}\frac{n}{\tilde{z}} \\
\text { 吾 }\end{array}$ & $\begin{array}{l}\frac{n}{\tilde{z}} \\
\text { 全 }\end{array}$ & 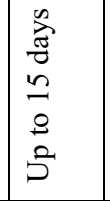 & 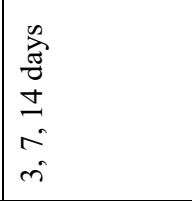 & 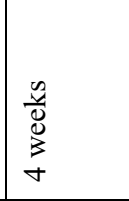 & 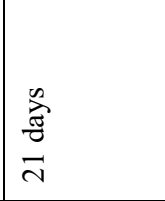 & 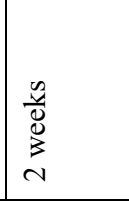 & \begin{tabular}{|l}
0 \\
0 \\
0 \\
0 \\
0 \\
0 \\
0 \\
0 \\
0 \\
0
\end{tabular} & 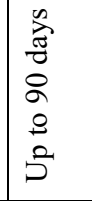 & 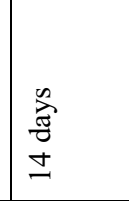 \\
\hline 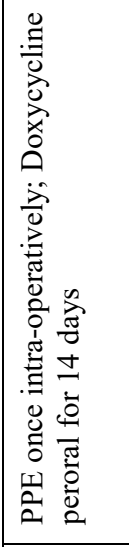 & 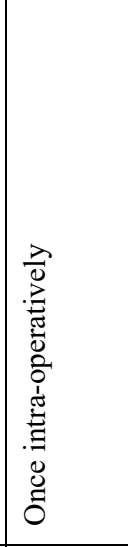 & 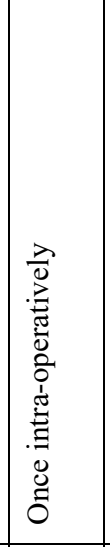 & 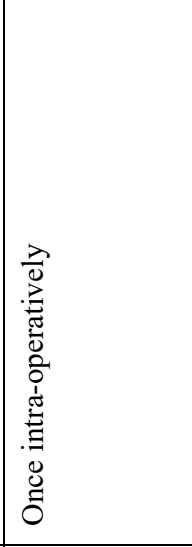 & 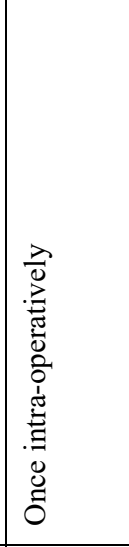 & 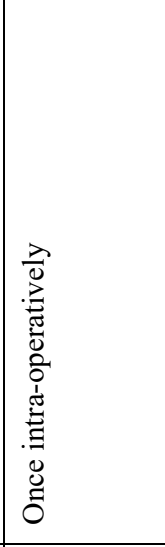 & 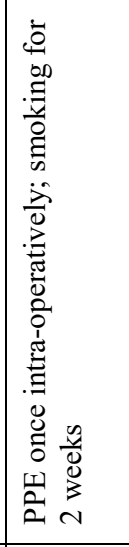 & 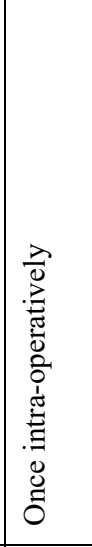 & $\overleftrightarrow{\mathrm{z}}$ & 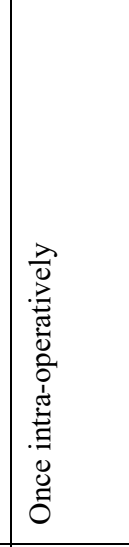 \\
\hline 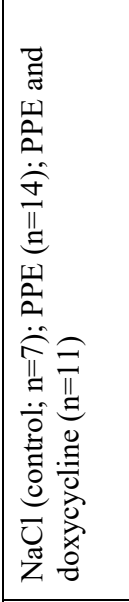 & 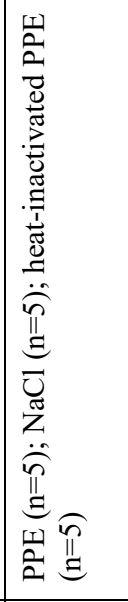 & 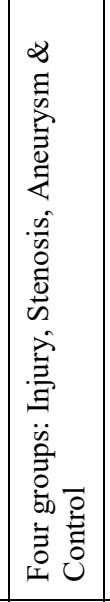 & 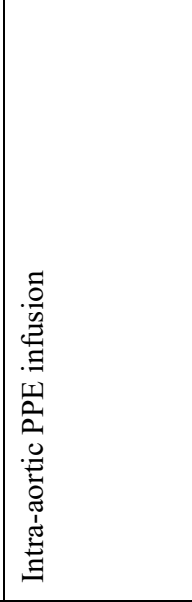 & 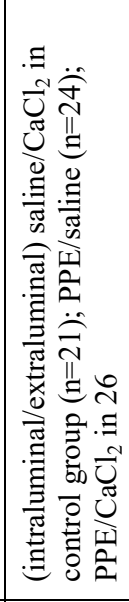 & 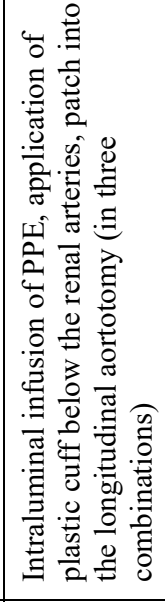 & 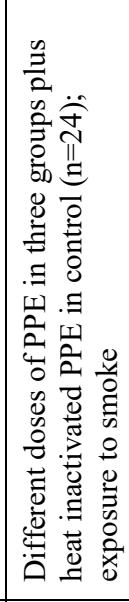 & 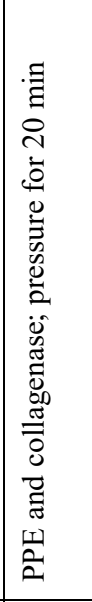 & 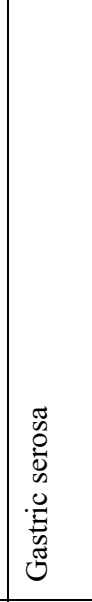 & 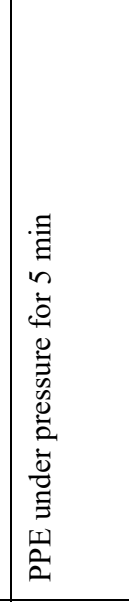 \\
\hline$\approx$ & 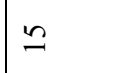 & 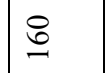 & $\tilde{z}$ & $\approx$ & $\pi$ & $\stackrel{\infty}{\curvearrowright}$ & $\stackrel{\circ}{\circ}$ & in & ป \\
\hline 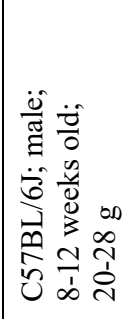 & 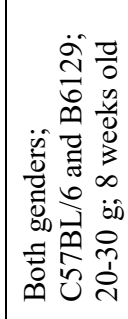 & 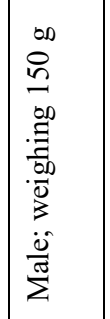 & 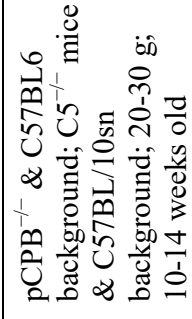 & 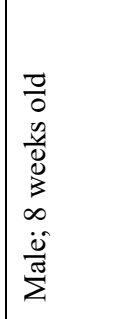 & 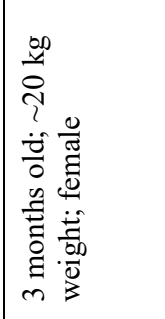 & 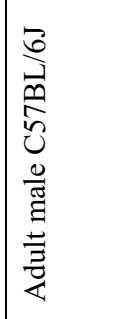 & 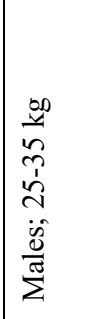 & 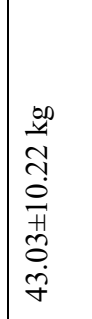 & 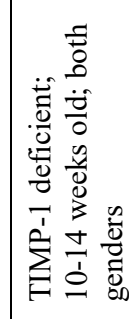 \\
\hline 迆 & $\frac{\mathscr{g}}{\Sigma}$ & 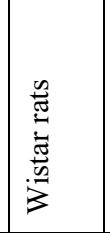 & 递 & 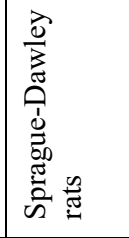 & $\frac{.50}{20.0}$ & 总 & 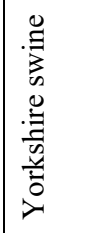 & 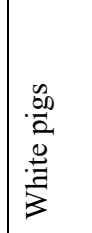 & 总 \\
\hline 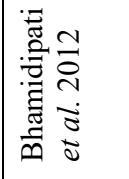 & 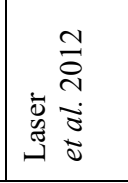 & 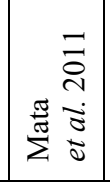 & 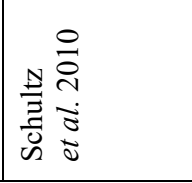 & 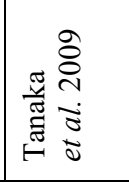 & 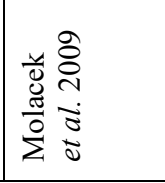 & 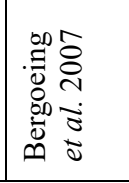 & 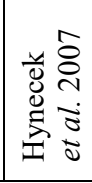 & 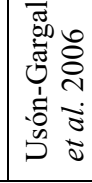 & 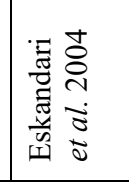 \\
\hline
\end{tabular}


dampening $\mathrm{T}$ cell and macrophage responses. CD8+ T cells are necessary for normal macrophage activation and interferon-s (IFN-s) is necessary for normal AAA development. CD43 ${ }^{-/}$CD8+T cells have a defect in producing IFN- $\gamma$, which leads to attenuation in AAA development.

Sharma et al. (2003) studied the formation of AAA in WT, IL- $23^{-/-}$or $\mathrm{IL}-17^{-/-}$mice using a PPE-perfusion model and abdominal aortic diameter was assessed on days 3, 7 and 14 following perfusion. Aortic diameter and cytokine production was significantly increased in PPE-perfused IL-17 $7^{-/-}$and IL-23 $3^{-1-}$ mice compared to WT mice on day 14. Cellular infiltration was significantly decreased in PPE-perfused IL-17 $7^{-1-}$ mice compared to WT mice on day 14.

Laser et al. (2012) studied MMP-9 and MMP-2 activity, macrophage count and aortic diameter in C57BL/6 and B6129 mice of both genders, after PPE periaortic infusion. Aortic diameter in $\mathrm{C} 57 \mathrm{BL} / 6$ and B6129 PPE treated male mice was larger compared to controls $(p=0.0028$ and $p<0.0001$, respectively). Similar changes of the aortic diameter were recorded in PPE treated female mice compared to controls $(p<0.0001$ and $p=0.0458$, respectively). The increase in macrophage count was statistically significant for all groups when compared to controls. MMP-9 and MMP-2 activity was increased in all groups for both genders. Female gender seemed to have lower concentrations of proinflammatory mediators that may play a role in the development of AAA, lower concentration of MMP-13 and higher concentration of collagen I and III in the post-infusion aortic wall (Laser et al. 2012, Laser et al. 2014).

Schultz et al. (2010) studied the effect of a single-dose intra-operative PPE infusion on an aortic segment of thrombin-activatable procarboxypeptidase $\mathrm{B}$ $\left(\mathrm{pCPB}^{-/}\right)$deficient mice. Mice were euthanized on day 3 , 7 and 14. The authors report that $\mathrm{pCPB}^{-/-}$mice presented a higher mortality rate from AAA rupture when their aortas were infused with standard PPE doses, when compared to WT mice. The latter presented smaller AAA than the $\mathrm{pCPB}^{-/-}$mice when the PPE concentration was lower than the usual. The authors conclude that CPB has a broad anti-inflammatory role in vivo and that enhanced AAA formation in the PPE model is the result of increased plasmin generation.

A slightly different approach was used by Tanaka et al. (2009) in their study on aortic dilation and aortic wall thickness. The authors simultaneously infused a section of rat infrarenal aorta with PPE while extraluminally applying a solution of sodium chloride. Rats in the control groups received either intraluminal or extraluminal infusion. At 4 weeks, success rate in the formation of an AAA was significantly higher in the simultaneous-infusion group (92.7\%), when compared to both the PPE-only infusion (25\%) and the extraluminal sodium-chloride-only infusion groups $(0 \%)$.

In 2004, Eskandari et al. (2005) studied the effect of intraluminal aortic PPE infusion in mice lacking the protective effect of TIMP. Control group received a saline infusion for the same period of time and at the same pressure as the study group. On the $14^{\text {th }}$ POD, $\mathrm{TIMP}^{-/-}$mice showed significant dilation of the aorta compared to the saline-infused $\mathrm{TIMP}^{-/-}$mice as well as to PPE-infused $\mathrm{TIMP}^{+/+}$mice $(\mathrm{p}<0.001$ and $\mathrm{p}=0.001$, respectively). From this study it becomes evident that TIMP has a protective role in the development of aneurysms.

\section{Calcium chloride $\left(\mathrm{CaCl}_{2}\right)$ model}

Bi et al. (2013b), 48 New Zealand white rabbits were equally divided into four groups, who were subjected to a 20-min periaortic incubation with different solutions. In the AAA model of one group $\mathrm{CaCl}_{2}$ $(0.5 \mathrm{~mol} / \mathrm{l})$ and PPE $(1 \mathrm{U} / \mathrm{ml})$ were used in a $1.5-\mathrm{cm}$ aortic segment. The second and third groups underwent incubation with either $\mathrm{CaCl}_{2}$ or PPE. The fourth group constituted the sham (control) group and saline was used for incubation. The diameter of the incubated aortic section was measured on days 5, 15 and 30. Animals were sacrificed on day 5 and day 30 for histopathological and immunohistochemical studies. All animals in the $\mathrm{CaCl}_{2} / \mathrm{PPE}$ group developed aneurysm, with an average dilation ratio of $65.3 \pm 8.9 \%$ on day $5,86.5 \pm 28.7 \%$ on day 15 and $203.6 \pm 39.1 \%$ on day 30 . This group exhibited less IMT, endothelial recovery, elastin and SMC content, but stronger expression of MMP-2, MMP-9 and a mouse monoclonal anti-rabbit macrophage antibody recognizing connective tissue and vascular macrophages (RAM11) compared to the controls. No aneurysm was found in the $\mathrm{CaCl}_{2}$-only group, and only one aneurysm was seen on day 5 in the PPE-only group.

Based on previous research from the 1950s and 1960 s on aortic calcification after $\beta$-aminopropionitrile ingestion in rats, Gertz et al. (1988) suggested that a pathogenic link between calcium deposition and aneurysm formation exist. In their study, aneurysm of the common carotid artery was produced in rabbits using periarterial application of $\mathrm{CaCl}_{2}$. By using a similar 
method, Freestone et al. (1997) reported the successful AAA induction in rabbits with the addition of the inflammatory-cell activator thioglycollate to the periaortic application of $\mathrm{CaCl}_{2}$. Formation and development of AAA under normolipidemic conditions using $\mathrm{CaCl}_{2}$ induction was reported with the introduction of the first reproducible $\mathrm{CaCl}_{2}$ murine model of AAA by Chiou et al. (2001). The histological and macroscopic features of this model resemble the alterations seen in fusiform human arterial aneurysms, such as calcium depositions occurring within the aortic media with destruction of elastic lamellae and SMC (Chiou et al. 2001). Influx of inflammatory cells and lack of thrombus have also been reported (Daugherty and Cassis 2004, Bi et al. 2013b, Powell 1991).

\section{Angiotensin II (AngII) model}

In a study by Ghoshal and Loftin (2012), AAAs were induced in hyperlipidemic apolipoprotein Edeficient mice (ApoE) by chronic AngII infusion and then the effect of treatment with the COX-2 inhibitor celecoxib was examined. The population of mice at 3.5 and 4-month age received continuous subcutaneous AngII infusion for 8 and 6 weeks at rates of 1 and $0.75 \mu \mathrm{g} / \mathrm{kg} / \mathrm{min}$, respectively. The two groups were sacrificed respectively at 6 and 8 weeks after the initiation of the infusion. Increase of the aortic diameter between mice receiving AngII for 1 week and 6 weeks was significantly higher in the second group ( $p<0.001)$.

Subcutaneous infusion of the AngII has been shown to promote the formation of aortic aneurysms in mice and the infusion effect is further intensified in hyperlipidemic mice strains, such as low-density lipoprotein receptor $\left(\mathrm{LDLR}^{-/-}\right)$deficient or ApoE $^{-/-}$deficient mice (Cassis et al. 2009, Daugherty et al. 2001, Inoue et al. 2009, Daugherty 2002). In these mouse strains, incidence and maximal diameter or postinfusion AAA are increased (Carell et al. 1999), although this AAA induction method might fail in creating a AAA in some AngII-infused hyperlipidemic mice (Rush et al. 2009). AAA created using this method showed some similarities, but also important differences, when compared to the AAA characteristics in humans. Similarities include the degradation of the aortic media layer, aortic dilation, higher incidence in males, presence of atherosclerosis and the presence of wall thrombus (Cassis et al. 2009, Borioni et al. 2005, Manning et al. 2002). Differences include significantly higher incidence of aortic dissection and rupture in AngII-infused mice than in humans; and AngII-infused mice present often with suprarenal AAA, when humans present a much higher incidence of infrarenal AAA (Saraff et al. 2003, Inoue et al. 2009). Expression of chymase, MMP-9, and angiotensin-converting enzyme is increased as a result of AngII infusion in hyperlipidemic mice (Inoue et al. 2009).

Recently, Folkesson et al. (2016) developed a zebrafish model for studying AAA, which have been lacking in the past and examined the role of AngII aortic infusion as well as cigarette smoke and snuff during the early stages of AAA development. Since its first appearance in research literature in 2001, the zebrafish has been an important animal model for studying vascular and lymphatic development. Vascular anatomical form and the molecular mechanisms underlying vessel formation in zebrafish are highly similar to those in humans (Gore et al. 2012).

\section{Combined models of chemical AAA induction}

Bergoeing et al. (2007) studied the development of AAA in $\mathrm{C} 57 \mathrm{BL} / 6 \mathrm{~J}$ mice using intraluminal aortic infusion of PPE in conjunction in pre-infusion cigarette smoking. Mice were infused with either high-dose PPE (HDE; $0.19 \mathrm{U} / \mathrm{ml}$ ), standard-dose (SDE; $0.16 \mathrm{U} / \mathrm{ml}$ ) or low-dose (LDE; $0.07 \mathrm{U} / \mathrm{ml}$ ). Control animals were infused with heat-inactivated PPE. After harvesting on the $14^{\text {th }}$ POD, SDE mice had developed an AAA, LDE mice had only developed a small dilation and HDE had developed an AAA but not significantly larger compared to the SDE mice. LDE mice exposed to cigarette smoking developed significantly larger aneurysms than smoke-free LDE mice $(\mathrm{p}=0.021)$.

Hynecek et al. (2007) studied the development of AAA in swine with the combined intraluminal infusion of PPE and collagenase. Aortic diameter was assessed by consequent MRI scans at 1, 3 and 6 weeks. Aortas were harvested at $24 \mathrm{~h}, 28 \mathrm{~h}, 1,2$ and 6 weeks. A significant gradual and persisting aortic dilation of $73.3 \pm 30.2 \%$ was observed. The outcomes of this study are not directly compared to a control group, as this was not included in the study design. Therefore the results should be taken under cautious consideration. Ji et al. (2014) have studied the effect of a cigarette component, 3,4-benzopyrene (BaP), and AngII in the development of AAA in C57/B6n mice. The method of delivery was either daily or weekly intraperitoneal injections. One group received a daily injection of AngII and a weekly injection of mediumchain triglycerides. Another group of mice received 
a weekly injection of $\mathrm{BaP}$ dissolved in medium-chain triglycerides. A third group only received a weekly injection of $\mathrm{BaP}$ dissolved in medium-chain triglycerides. The control group received only a weekly injection of medium-chain triglycerides. At 5 weeks, the AngII/BaP group presented with a higher increase of the aortic diameter and aortic muscle cell apoptosis compared to the AngII group ( $<0.05$ for both). Similar were the results for aortic macrophage infiltration, expression for MMP-2, MMP-9, MMP-12 and levels of nuclear factor- $\mathrm{KB}$; all significantly increased in the AngII/BaP group compared to the AngII group $(p<0.05)$. Findings were similar to Bergoeing's, showing a relation between cigarette components and AAA development.

Czerski et al. (2013) studied the effect of mechanical stretching in combination with PPE and/or collagenase infusions with or without the extraluminal application of $\mathrm{CaCl}_{2}$. Mechanical aortic stretching was achieved with the use of a Foley catheter. The aorta of one group of swines was mechanically stretched and then infused with $500 \mathrm{U}$ of PPE under pressure. The second group was subjected to the same procedure but the infusion also contained 6,000 IU of collagenase and total infusion volume and pressure was not changed. The third group was subjected to the same procedure as the second one but there was a 20-min extraluminal application of $0.5 \mathrm{M}$ solution of $\mathrm{CaCl}_{2}$. The aortic diameter was measured through ultrasonography on a weekly basis up to the $4^{\text {th }}$ postoperative week, when the piglets were euthanized and the aortas were harvested. In the first group immediate postoperative dilation was observed, but the increase was quickly regressed and none of the subjects' aortas qualify as aneurysmatic. The aortas of the second and third groups did qualify as aneurysmatic when compared to normal swine aortic diameter $(p \leq 0.001$ for both groups). Especially in the third group, large calcium depositions, apoptosis of the SMC, destruction of elastin fibers and inflammation-related changes were observed in the posthumous pathologic examination.

In a recent study of Bi et al. (2015), 51 male white rabbits were divided into four groups: group $\mathrm{S}$ that had a suture placed under the renal arteries causing an aortic stenosis, group $\mathrm{E}$ that had the infrarenal aorta bathed in $60 \mathrm{ml}$ of $1 \mathrm{U} / \mathrm{ml}$ solution of porcine PPE for $10 \mathrm{~min}$, group SE that received both the stenosis and the PPE treatment, and the control group that received a sham operation. All animals in group SE developed an aneurysm by week 2 and this diameter increase was significant by week 16 ( $<<0.01$ vs. week 8$)$. Group SE showed insignificant media thickness decrease and insignificant SMC content decrease. SMC content in group E was increased compared to the control group, where group S showed significant SMC content decrease by week 8 . All animals in group $\mathrm{E}$ developed an aneurysm by week 4 and the diameter increase was significant by week 8 ( $p<0.05$ vs. group $\mathrm{E}$ ). In group $\mathrm{E}$ only one aneurysm was developed and subsequently the aortic diameter decreased and did not differ from the control group. All groups showed a decrease of elastin content in the aortic wall, but only group E demonstrated a tendency to increase after the initial drop of aortic content.

Tanaka et al. (2014), treated the infrarenal aorta of 58 male rats with intraluminal PPE $30 \mathrm{ml}$ solution and $0.5 \mathrm{M} \mathrm{CaCl}_{2}$ soaked gauze was wrapped around the region simultaneously for $20 \mathrm{~min}$. Apart from the control group (group $\mathrm{C} ; \mathrm{n}=18)$, the rest of the animals $(\mathrm{n}=16)$ were equally divided into two groups; group $\mathrm{G}$ had the aorta wrapped in saline-impregnated gelatin hydrogel sheet, while group A in ascorbic acid-impregnated gelatin hydrogel sheet. All animals in groups C and G developed aneurysms by week 4 and week 8 , respectively. Animals in group A did not develop an aneurysm by week 4 and only $16.7 \%$ did so by week 8 . Dilatation rates in aneurysms of group A were significantly lower than those in groups $\mathrm{C}$ and $\mathrm{G}$. Collagen and elastin content of group A was significantly higher than the other two groups. The authors concluded that the ascorbic acid has a protective role in AAA formation.

\section{Surgical induction}

Experimental AAAs in animal models can be created by exerting force or pressure, and creating a mechanical weakness within the arterial wall. This may be achieved through direct and indirect injuries (Schmoker et al. 2008), aortic constriction and intraluminal pressure. The latter is also used in the majority of the chemical AAA induction models with the intraluminal exertion of pressure with the infusion of PPE or other.

A frequently-used approach uses a patch to repair the site of the aortotomy as a structurally weaker graft which postoperatively dilates (German and Black 1954). This patch often of vein or serosa origin, although synthetic patches have also been used. A significant number of modifications of the original protocol have been proposed, aiming in higher incidence of AAA induction with predictable results (Huynh et al. 
2007, Kajimoto et al. 2008, Lerouge et al. 2004, Murphy et al. 2007, Scholz et al. 2008, Mucke et al. 2008, Allaire et al. 2002, Soulez et al. 2007). Despite many similarities existing between surgically induced AAA in animal models and human AAA development, such as main AAA morphological characteristics, there are noticeable differences, such as the increase of SMC and aortic fibroblasts in some animal models that come into contradictions with the human AAA development process (Molacek et al. 2009, Scholz et al. 2008, Mucke et al. 2008).

Aortic dilation can be induced by altering blood flow within the aorta, causing turbulence and shear stress as a result of external artificial reductions in the aortic diameter by constriction. Aortic dilation induced through hemodynamic alteration does not form at the point of the manipulation, but develops post-stenotically. As demonstrated by some authors (Molacek et al. 2009), surgical techniques can also be used in combination with other aneurysm induction techniques in order to exacerbate AAA induction.

Surgical implantation of xeno- or allograft arterial tissues generates an aneurysm phenotype within 4 postoperative weeks, due to immune rejection of the implanted tissue. This method has been widely employed by Allaire et al. (2002), who induced aneurysms in Fischer rats by implantation of aortic sections harvested from Hartley guinea pig. These studies have shown that overexpression of protease inhibitors within the aortic tissues prevents the degeneration of elastin within the arterial wall, although these interventions did not appear to alter the invasion of inflammatory cells (Allaire et al. 1998a,b, Qian et al. 2008). These studies by a number of publications of Allaire et al. (1998a,b) demonstrated significant reductions in AAA formation, elastin degeneration, and reduced inflammatory infiltration after seeding grafted tissue with syngenic rat aortic SMCs, due to the protective effect of SMC-mediated repair of the aortic media through secretion of elastin and collagen (Allaire et al. 2002, Ross et al. 1971, Zhang et al. 2003). On the other hand, evidence also suggests that the SMCs can secrete PPE and MMP-9, both involved in the destruction of the extracellular matrix (Cohen et al. 1992, Patel et al. 1996).

Lin et al. (2013) have used a different approach to induce AAA development in mini pigs. Funnel-shaped expanded polytetrafluoroethylene strip was placed circumferentially $2 \mathrm{~cm}$ above the aortic bifurcation, creating a tapered channel with a nonconstrictive inlet and a constrictive outlet and thus causing coarctation of the aorta. At 4, 8 and 12 weeks the aortas were harvested and results showed that mini pigs in all three harvesting groups had developed AAA compared to the control group ( $\mathrm{p}<0.01, \mathrm{p}<0.01$ and $\mathrm{p}<0.001$, respectively). The 12 -week group also showed a significant decrease in aortic wall elastic fibers $(\mathrm{p}<0.05)$ compared to the control group.

Mata et al. (2011) based on two components of the AAA development - turbulence and inflammation studied the effect of seldom aortic injury, seldom stenosis and both stenosis and injury on rats. One group of rats received an injury on the external aortic all, the second group received a constriction of the aorta and the third group received both. A fourth group acted as a control, receiving a sham laparotomy without any further procedures. Rats were sacrificed at 1, 3, 7, 15 days after laparotomy. Aortic wall thickness was significantly increased in the 3, 7 and 15-day injury/ stenosis groups compared to the sham group $(\mathrm{p}<0.001)$. Elastic fibers in the aortic wall were significantly reduced in these three groups $(p<0.001)$. Collagen fibers were increased in the aortic wall of the already mentioned three groups ( $p<0.05$ for the 7-day group and $p<0.001$ for the rest). Similarly, the aortic diameter could be classified as aneurysmatic only in the stenosis/injury group starting from the $3^{\text {rd }} P O D$ up to day $15(p<0.001)$. The groups who underwent either stenosis or injury did not show significant changes compared to the control group.

Usón-Gargallo et al. (2006) studied the use of serosa autologous patch in the development of AAA in five pigs. The especially serosa patch was specially prepared to have only its visceral surface expose and it was then sutured on the site of the aortotomy. Animals were followed up using angiography and ultrasonography on postoperative days $7,14,30,45,60$, and 90 , when animals were sacrificed. Two animals died because of AAA rupture on days 6 and 10 (40\% rupture rate) and one more had to be euthanized due to paraplegia on day 30. Aortic diameter reached a peak at day 30 and then it decreased (Usón-Gargallo et al. 2006). No statistically significant changes in the aortic diameter were reported and the only statistically significant increase was showed between the preoperative and the immediate postoperative aortic diameter $(\mathrm{p}=0.042)$.

Recently, Tanaka et al. (2015) evaluated whether hypoperfusion of the adventitial vasa vasorum (VV) could develop AAAs by creating a rat model of adventitial VV hypoperfusion with a combination of 
a polyurethane catheter insertion and a suture ligation of the infrarenal abdominal aorta. VV hypoperfusion caused tissue hypoxia and developed infrarenal AAA, which had similar morphological and pathological characteristics to human AAA. More specifically, by using serial ultrasounds the authors showed the first presence of ILT on POD 14 and extended to the entire circumference of the aorta by POD 28. The AAA developed in a fusiform shape between the aortic ligation and the aortic bifurcation with progressively thinner medial layer. In addition, elastic fiber fragmentation in the aortic media and sparse collagen fibers in the aortic adventitia were observed at POD 28. In human AAA tissue, the adventitial VV were stenotic in both small AAAs (30-49 $\mathrm{mm}$ in diameter) and in large AAAs (>50 $\mathrm{mm}$ in diameter), with the sac tissue in these AAAs being ischemic and hypoxic. These results indicate that hypoperfusion of adventitial VV has critical effects on the development of infrarenal AAA.

\section{Diet-based model}

Li et al. (2013) studied the effect of 8-week high-fat diet on two groups of $\mathrm{ApoE}^{-/-}$mice. Only one of the groups overexpress ET-1 selectively in endothelium (eET1). eET1/ApoE ${ }^{-/-}$mice showed an increased tendency for AAA development when compared to wild type on high-fat diet, to $\mathrm{ApoE}^{-/-}$mice and to eET1 mice ( $<0.01$ for all groups).

\section{Discussion}

There is a great need for a better understanding of the pathophysiology of AAA, and animal models are increasingly being used in such studies. This review is therefore timely and a good support for AAA researchers. In current literature, a variety of different animal models is subjected to either chemical or surgical induction of AAA. These animals vary from rodents (mice or rats) to larger animals, such as pigs and in some cases canines, the use of the latter still being controversial (Trollope et al. 2011). This research for new and better animal models is evident as zebrafish was recently used for the first time in AAA research by Folkesson et al. (2016). Animal models subjected to AAA induction could either be wild-types or genetically manipulated animals.

Medial degeneration with simultaneous destruction of SMC and the elastic lamellae is a pathognomonic sign of human aneurysmatic aorta and it is evident in all AAA induction studies on animal models, whether induction is chemical or surgical on WT or genetically manipulated individuals. Evidence also suggests that the inflammatory process is essential for AAA formation in humans and that certain inflammatory mediators (especially MMP-2 and MMP-9) play a key role. This inflammatory process is evident in aorta harvested from animals subjected to chemical induction. This key role of inflammation in the AAA development is also supported by studies on $\mathrm{LTB}_{4}$ deficient mice and "blotchy mice" that lack a proper inflammatory response and fail to develop AAA. Atherosclerosis also play a role in AAA development in humans and certain induction methods in animals seem to activate the formation of atherosclerosis. These genetically manipulated mice also show increased intra-aortic thrombus formation, another process related to the development of AAA in humans. Mast cells have been found to participate in human aortic disease, including atherosclerosis and AAA. Sun et al. (2007) demonstrated that mast cells control the process of chemically induced AAAs in mice, and reported that PPE perfusion did not result in aortic dilation in mast-cell deficient mice, while aortas from WT controls showed a significant dilation. An immediate but transient postinfusion aortic dilation of approximately $30 \%$ was reported in mast-cell deficient mice, possibly as a result of the mechanical injury of the infusion process itself, and aortic elastic fibers and media SMC were better preserved. Similar were the results of mast-cell deficient mice receiving a periaortic application of $\mathrm{CaCl}_{2}$. These findings confirm the important role of mast cells in SMC apoptosis and medial degeneration, both processes associated with AAA formation. These findings were further supported by the work of Tsuruda et al. (2008) also performed on mast-cell deficient rats.

Induction of experimental AAA using intraoperative intraluminal perfusion of the abdominal aorta with PPE was first reported in the 1960s in studies using canine models (Economou et al. 1960, Nabseth et al. 1963). These studies reported the development of aortic aneurysm within 2 months. Based on this experience, Anidjar et al. (1990) further developed a rat model in which $2 \mathrm{~h}$ of intraluminal perfusion with PPE under pressure completely destroyed the elastic fibers of an aortic segment in a period of 3 weeks. The method has been recently described online in detail by Azuma et al. (2009). Since the first studies using PPE induced AAA, this method has been widely and frequently used across a broad spectrum of animal species, and it has been subjected to improvements or variations, such as one 
suggested by Yamaguchi et al. (2001, 2000), reporting that morphologic changes associated with PPE infusion are complete after $1 \mathrm{~h}$, and suggesting that a perfusion time ranging from 60 to $120 \mathrm{~min}$ is sufficient to induce AAA in rat models. PPE induction of AAA in rats shows similar temporal and pathophysiological characteristics as in humans, such as the correlation of aortic dilation with the intensity of the inflammatory response, leading to the destruction of the medial elastic tissue (Pyo et al. 2000, Halpern et al. 1994). Despite 91-100 \% success rates in AAA induction in smaller animals, PPE induction in larger animals model does not yield similarly good results (Pyo et al. 2000, Marinov et al. 1997). Similarly, PPE induction is less successful in female animals. From a technical point of view, AAA induction with PPE infusion requires cannulation of the rodent aorta and leakage of the PPE solution during perfusion is frequent; both leading to the death of the animal.

Discrepancies exist in the rate of aneurysm development following aortic PPE infusion (Moris et al. 2015). Yamaguchi et al. (2000) report that aortic diameter and wall structure remain stable for up to 1 week after the infusion, after which a significantly higher rate of aortic dilation occurs. In contrast, Dobrin (1999) reported a $30 \%$ aortic dilation immediately after PPE perfusion, followed by significant aortic dilation in the subsequent days, and this was supported by early histological examination, confirming the destruction of the elastic fibers, followed by influx of inflammatory cells, both known to be related with AAA formation. Similar results were reported by several studies published after 2004 and they all show early AAA formation following the PPE induction, decrease in the media thickness, destruction of the elastin lamellae and presence of inflammatory mediators (Bi et al. 2013a,b, Bhamidipati et al. 2012, Molacek et al. 2009).

The $\mathrm{CaCl}_{2}$-induced AAA model, which was first introduced by Gertz et al. (1988) in the rabbit carotid artery and was later used in the aorta, is another frequently used model (Freestone et al. 1997). Chiou et al. (2001) demonstrated that peri-aortic application of $\mathrm{CaCl}_{2}$ to the infrarenal aorta of mice for $10 \mathrm{~min}$ successfully induces AAA. A wide variety of $\mathrm{CaCl}_{2}$ concentrations are reported by numerous studies, concentrations that differ for each kind of rodent used. In rodents, the aortic exposure to $\mathrm{CaCl}_{2}$ leads to the destruction of the elastin fibers of the aortic wall and the infiltration of inflammatory cells to the intima and medial layers within 7 and 3 days after induction, respectively.
Periaortic $\mathrm{CaCl}_{2}$ application is not reliable in AAA induction, with only approximately two thirds of rats developing aneurysms, even when an arbitrary threshold of a $20 \%$ diameter increase to define AAA was used (Isenburg et al. 2007).

AngII perfusion needs effective micro-pumps and animals tend to form suprarenal aneurysms, not typical for humans. AngII perfusion in C57BL/6 mice produce AAA in $39 \%$ of cases, but $\mathrm{ApoE}^{-/-}$or $\mathrm{LDLR}^{-/-}$animals develop AAA in approximately $100 \%$. Genetically manipulated $\mathrm{ApoE}^{-/}$or $\mathrm{LDLR}^{-/}$animals need long periods of time to cross-breed and inbreeding might result in lethal genome. AngII model is based on the simulation of the inflammatory process caused by the AngII infusion, which in the case of $\mathrm{ApoE}^{-/}$mice, mimics the human inflammatory process. This model is technically less challenging than the PPE model as there is no need for major surgical manipulation of mice. This AAA induction method often leads to rupture.

Genetic manipulation of specific genes in order to study their involvement and role in a specific path of disease pathogenesis is a valuable tool for either understanding the mechanisms behind disease pathogenesis or highlighting potential future therapeutic targets. Focused disruption of one or more gene alleles results in the creation of strains deficient animals, called gene knockout animals in modern literature, and provides useful information on the pathophysiology of specific health issues, or of vascular disease in our case (Daugherty 2002). Despite the wide variety of gene knockout animal strains available, only a small number of them have been used in AAA formation and development research.

Aziz and Kuivaniemi (2007) have discussed in detail the role of MMPs secreted from inflammatory cells in the degeneration of medial elastin and collagen fibers; something that Silence et al. (2002) have simulated by $\mathrm{ApoE}^{-/-}$mice and TIMP-1 ${ }^{-/-}$mice, finally demonstrating that the tendency of hyperlipidemic mice to develop smaller aneurysms was significantly exacerbated in the absence of TIMP-1. Both the destruction of aortic wall and the connection of unregulated MMP activity with the development of larger aneurysms are findings consistent with results reported from human aneurysm studies. An interesting characteristic of $\mathrm{ApoE}^{-/-} \mathrm{TIMP}_{-1}^{-/-}$ animals is the reduced atherosclerotic process, suggesting that this strain may be the animal model to use for AAA-specific research (Silence et al. 2002). MMP role in the formation and development of AAA has been in the 
focus of many published results, such as by Pyo et al. (2000) who confirmed the role for MMP-9 in the continued destruction of the medial elastic fibers contrary to that of MMP-12 that did not have a significant impact of AAA formation.

The importance of the signaling pathway mediated by leukotriene $\mathrm{B} 4\left(\mathrm{LTB}_{4}\right)$ and by the G-coupled receptor protein $\left(\mathrm{BLT}_{1}\right)$ in the pathogenesis of $\mathrm{AAA}$ has been recently demonstrated in a study by Ahluwalia et al. (2007), utilizing ApoE ${ }^{-/-} \mathrm{BLT}_{1}{ }^{-/}$double knockout mice. $\mathrm{LTB}_{4}$ drives a pro-inflammatory response by binding to the high-affinity receptor $\mathrm{BLT}_{1}$, eliciting a signaling cascade that results in production of inflammatory mediators and MMPs (Ahluwalia et al. 2007).

Apart to disrupting genes, mutation induction can be used to generate faulty protein products, an approach already used to generate animal strains that develop aortic aneurysms. An example of this genetic manipulation is the mouse model of Marfan syndrome (MS) first reported by Pereira et al. (1997), where mice display a disorder similar to human MS patients, as a result of homozygous mutations in the fibrillin-1 gene (Ammash et al. 2008, Pereira et al. 1997, Pereira et al. 1999). These animals often develop aneurysms at the aortic root and die spontaneously from rupture of the thoracic aorta (Xiong et al. 2008). Since thoracic aneurysm rupture is a frequent condition leading to premature death in humans, the mouse MS disease model has been very useful in studying mechanisms and testing the effectiveness of therapeutic interventions against MS (Pyo et al. 2000, Xiong et al. 2008).

All animal models have common and crucial limitations. First, any resemblance between animal models and natural human aneurysms is based on tissue samples from end-stage disease. Aneurysm formation in humans is a long process, usually several years, and the underlying pathophysiological process behind it is mostly unknown. This is illustrated by the fact that results from animal AAA-model studies have consistently been very difficult to be reproduced in humans. This is a central limitation with all models and should be taken into consideration when evaluating the results from AAA animal models. Second, the reported diameter expansion rates and measurements have a degree of measuring error. In order for all published data to be comparative, researchers should decide in one measuring method, either ultrasound or direct measurement after laparoscopy with both these methods carrying their own advantages and disadvantages.

Despite the technical difficulties and the limitations of the above-mentioned methods, each AAA induction model has its respective advantages and it is useful for the study of AAA development in humans. Using any method should be chosen based on the aim of the research and after careful consideration of proximity of the selected method to human pathophysiological mechanisms of AAA development.

\section{Conclusions}

A number of different approaches of AAA induction in animal models has been developed, used and combined since the first report in the 1960's. Although all the above-mentioned methods are successful in AAA induction in animal models, it is necessary that these methods and their respective results are in line with the pathophysiology and the mechanisms involved in human AAA development.

\section{Conflict of Interest}

There is no conflict of interest.

\section{Acknowledgements}

The team of authors would like to thank Mr. P. Tsakiropoulos and Mrs C. Paza for their help.

\section{References}

AHLUWALIA N, LIN AY, TAGER AM, PRUITT IE, ANDERSON TJ, KRISTO F, SHEN D, CRUZ AR, AIKAWA M, LUSTER AD, GERSZTEN RE: Inhibited aortic aneurysm formation in BLT1-deficient mice. J Immunol 179: 691-697, 2007.

ALLAIRE E, FOROUGH R, CLOWES M, STARCHER B, CLOWES AW: Local overexpression of TIMP-1 prevents aortic aneurysm degeneration and rupture in a rat model. J Clin Invest 102: 1413-1420, 1998a.

ALlAire E, HASENSTAB D, KENAGY RD, STARCHER B, CLOWES MM, CLOWES AW: Prevention of aneurysm development and rupture by local overexpression of plasminogen activator inhibitor-1. Circulation 98: 249-255, $1998 \mathrm{~b}$. 
ALLAIRE E, MUSCATELLI-GROUX B, MANDET C, GUINAULT AM, BRUNEVAL P, DESGRANGES P, CLOWES A, MELLIERE D, BECQUEMIN JP: Paracrine effect of vascular smooth muscle cells in the prevention of aortic aneurysm formation. J Vasc Surg 36: 1018-1026, 2002.

AMMASH NM, SUNDT TM, CONNOLLY HM: Marfan syndrome-diagnosis and management. Curr Probl Cardiol 33: 7-39, 2008.

ANIDJAR S, SALZMANN JL, GENTRIC D, LAGNEAU P, CAMILLERI JP, MICHEL JB: Elastase-induced experimental aneurysms in rats. Circulation 82: 973-981, 1990.

AOKI H, YOSHIMURA K, MATSUZAKI M: Turning back the clock: regression of abdominal aortic aneurysms via pharmacotherapy. J Mol Med 85: 1077-1088, 2007.

AZIZ F, KUIVANIEMI H: Role of matrix metalloproteinase inhibitors in preventing abdominal aortic aneurysm. Ann Vasc Surg 21: 392-401, 2007.

AZUMA J, ASAGAMI T, DALMAN R, TSAO PS: Creation of murine experimental abdominal aortic aneurysms with elastase. J Vis Exp 29: 1280, 2009.

BERGOEING MP, ARIF B, HACKMANN AE, ENNIS TL, THOMPSON RW, CURCI JA: Cigarette smoking increases aortic dilatation without affecting matrix metalloproteinase- 9 and -12 expression in a modified mouse model of aneurysm formation. J Vasc Surg 45: 1217-1227, 2007.

BHAMIDIPATI CM, MEHTA GS, LU G, MOEHLE CW, BARBERY C, DIMUSTO PD, LASER A, KRON IL, UPCHURCH GR JR, AILAWADI G: Development of a novel murine model of aortic aneurysms using periadventitial elastase. Surgery 152: 238-246, 2012.

BI Y, ZHONG H, XU K, NI Y, QI X, ZHANG Z, LI W: Performance of a modified rabbit model of abdominal aortic aneurysm induced by topical application of porcine elastase: 5-month follow-up study. Eur J Vasc Endovasc Surg 45: 145-152, 2013a.

BI Y, ZHONG H, XU K, ZHANG Z, QI X, XIA Y, REN L: Development of a novel rabbit model of abdominal aortic aneurysm via a combination of periaortic calcium chloride and elastase incubation. PLoS One 8: e68476, $2013 b$.

BI Y, ZHONG H, XU K, QI X, ZHANG Z, WU G, HAN X: Novel experimental model of enlarging abdominal aortic aneurysm in rabbits. J Vasc Surg 62: 1054-1063, 2015.

BIGATEL DA, ELMORE JR, CAREY DJ, CIZMECI-SMITH G, FRANKLIN DP, YOUKEY JR: The matrix metalloproteinase inhibitor BB-94 limits expansion of experimental abdominal aortic aneurysms. J Vasc Surg 29: 130-138, 1999.

BORIONI R, GAROFALO M, DE PAULIS R, NARDI P, SCAFFA R, CHIARIELLO L: Abdominal aortic dissections: anatomic and clinical features and therapeutic options. Tex Heart Inst J 32: 70-73, 2005.

CARRELL TW, SMITH A, BURNAND KG: Experimental techniques and models in the study of the development and treatment of abdominal aortic aneurysm. Br J Surg 86: 305-312, 1999.

CASSIS LA, GUPTE M, THAYER S, ZHANG X, CHARNIGO R, HOWATT DA, RATERI DL, DAUGHERTY A: ANG II infusion promotes abdominal aortic aneurysms independent of increased blood pressure in hypercholesterolemic mice. Am J Physiol 296: H1660-H1665, 2009.

CENTER FOR DISEASE CONTROL: Deaths, percent of total deaths, and death rates for the 15 leading causes of death in 5-year age groups, by race, and sex: United States, 2014. Available from: https://www.cdc.gov/nchs/data/dvs/lcwk1_2014.pdf

CHIOU AC, CHIU B, PEARCE WH: Murine aortic aneurysm produced by periarterial application of calcium chloride. $J$ Surg Res 99: 371-376, 2001.

COHEN JR, SARFATI I, DANNA D, WISE L: Smooth muscle cell elastase, atherosclerosis, and abdominal aortic aneurysms. Ann Surg 216: 327-330, 1992.

CZERSKI A, BUJOK J, GNUS J, HAUZER W, RATAJCZAK K, NOWAK M, JANECZEK M, ZAWADZKI W, WITKIEWICZ W, RUSIECKA A: Experimental methods of abdominal aortic aneurysm creation in swine as a large animal model. J Physiol Pharmacol 64: 185-192, 2013.

DAUGHERTY A: Mouse models of atherosclerosis. Am J Med Sci 323: 3-10, 2002.

DAUGHERTY A, CASSIS LA: Mouse models of abdominal aortic aneurysms. Arterioscler Thromb Vasc Biol 24: 429-434, 2004. 
DAUGHERTY A, MANNING MW, CASSIS LA: Antagonism of AT2 receptors augments angiotensin II-induced abdominal aortic aneurysms and atherosclerosis. Br J Pharmac 134: 865-870, 2001.

DOBRIN PB: Animal models of aneurysms. Ann Vasc Surg 13: 641-648, 1999.

ECONOMOU SG, TAYLOR CB, BEATTIE EJ JR, DAVIS CB JR: Persistent experimental aortic aneurysms in dogs. Surgery 47: 21-28, 1960.

ERNST CB: Abdominal aortic aneurysm. N Engl J Med 328: 1167-1172, 1993.

ESKANDARI MK, VIJUNGCO JD, FLORES A, BORENSZTAJN J, SHIVELY V, PEARCE WH: Enhanced abdominal aortic aneurysm in TIMP-1-deficient mice. J Surg Res 123: 289-293, 2005.

FOLKESSON M, SADOWSKA N, VIKINGSSON S, KARLSSON M, CARLHALL CJ, LANNE T, WAGSATER D, JENSEN L: Differences in cardiovascular toxicities associated with cigarette smoking and snuff use revealed using novel zebrafish models. Biol Open 5: 970-978, 2016.

FREESTONE T, TURNER RJ, HIGMAN DJ, LEVER MJ, POWELL JT: Influence of hypercholesterolemia and adventitial inflammation on the development of aortic aneurysm in rabbits. Arterioscler Thromb Vasc Biol 17: 10-17, 1997.

GERMAN WJ, BLACK SP: Experimental production of carotid aneurysms. N Engl J Med 250: 104-106, 1954.

GERTZ SD, KURGAN A, EISENBERG D: Aneurysm of the rabbit common carotid artery induced by periarterial application of calcium chloride in vivo. J Clin Invest 81: 649-656, 1988.

GHOSHAL S, LOFTIN CD: Cyclooxygenase-2 inhibition attenuates abdominal aortic aneurysm progression in hyperlipidemic mice. PLoS One 7: e44369, 2012.

GORE AV, MONZO K, CHA YR, PAN W, WEINSTEIN BM: Vascular development in the zebrafish. Cold Spring Harb Perspect Med 2: a006684, 2012.

HALPERN VJ, NACKMAN GB, GANDHI RH, IRIZARRY E, SCHOLES JV, RAMEY WG, TILSON MD: The elastase infusion model of experimental aortic aneurysms: synchrony of induction of endogenous proteinases with matrix destruction and inflammatory cell response. J Vasc Surg 20: 51-60, 1994.

HENDERSON EL, GENG YJ, SUKHOVA GK, WHITTEMORE AD, KNOX J, LIBBY P: Death of smooth muscle cells and expression of mediators of apoptosis by $\mathrm{T}$ lymphocytes in human abdominal aortic aneurysms. Circulation 99: 96-104, 1999.

HOLMES DR, PETRINEC D, WESTER W, THOMPSON RW, REILLY JM: Indomethacin prevents elastase-induced abdominal aortic aneurysms in the rat. $J$ Surg Res 63: 305-309, 1996.

HUYNH H, ELKOURI S, BEAUDOIN N, BRUNEAU L, GUIMOND C, DANIEL V, BLAIR JF: Totally laparoscopic aortic surgery: comparison of the apron and retrocolic techniques in a porcine model. Vasc Endovascular Surg 41: 230-238, 2007.

HYNECEK RL, DERUBERTIS BG, TROCCIOLA SM, ZHANG H, PRINCE MR, ENNIS TL, KENT KC, FARIES PL: The creation of an infrarenal aneurysm within the native abdominal aorta of swine. Surgery 142: 143-149, 2007.

INOUE N, MURAMATSU M, JIN D, TAKAI S, HAYASHI T, KATAYAMA H, KITAURA Y, TAMAI H, MIYAZAKI M: Involvement of vascular angiotensin II-forming enzymes in the progression of aortic abdominal aneurysms in angiotensin II- infused ApoE-deficient mice. J Atheroscler Thromb 16: 164-171, 2009.

ISENBURG JC, SIMIONESCU DT, STARCHER BC, VYAVAHARE NR: Elastin stabilization for treatment of abdominal aortic aneurysms. Circulation 115: 1729-1737, 2007.

JI K, ZHANG Y, JIANG F, QIAN L, GUO H, HU J, LIAO L, TANG J: Exploration of the mechanisms by which 3,4-benzopyrene promotes angiotensin II-induced abdominal aortic aneurysm formation in mice. J Vasc Surg 59: 492-499, 2014.

KAJIMOTO M, SHIMONO T, HIRANO K, MIYAKE Y, KATO N, IMANAKA-YOSHIDA K, SHIMPO H, MIYAMOTO K: Basic fibroblast growth factor slow release stent graft for endovascular aortic aneurysm repair: a canine model experiment. J Vasc Surg 48: 1306-1314, 2008. 
LASER A, LU G, GHOSH A, ROELOFS K, MCEVOY B, DIMUSTO P, BHAMIDIPATI CM, SU G, ZHAO Y, LAU CL, AILAWADI G, ELIASON JL, HENKE PK, UPCHURCH GR JR: Differential gender- and speciesspecific formation of aneurysms using a novel method of inducing abdominal aortic aneurysms. $J$ Surg Res 178: 1038-1045, 2012.

LASER A, GHOSH A, ROELOFS K, SADIQ O, MCEVOY B, DIMUSTO P, ELIASON J, UPCHURCH GR JR: Increased estrogen receptor alpha in experimental aortic aneurysms in females compared with males. $J$ Surg Res 186: 467-474, 2014.

LEROUGE S, RAYMOND J, SALAZKIN I, QIN Z, GABOURY L, CLOUTIER G, OLIVA VL, SOULEZ G: Endovascular aortic aneurysm repair with stent-grafts: experimental models can reproduce endoleaks. $J$ Vasc Interv Radiol 15: 971-979, 2004.

LI MW, MIAN MO, BARHOUMI T, REHMAN A, MANN K, PARADIS P, SCHIFFRIN EL: Endothelin-1 overexpression exacerbates atherosclerosis and induces aortic aneurysms in apolipoprotein $\mathrm{E}$ knockout mice. Arterioscler Thromb Vasc Biol 33: 2306-2315, 2013.

LIN PY, WU YT, LIN GC, SHIH YH, SAMPILVANJIL A, CHEN LR, YANG YJ, WU HL, JIANG MJ: Coarctationinduced degenerative abdominal aortic aneurysm in a porcine model. J Vasc Surg 57: 806-815, 2013.

LONGO GM, BUDA SJ, FIOTTA N, XIONG W, GRIENER T, SHAPIRO S, BAXTER BT: MMP-12 has a role in abdominal aortic aneurysms in mice. Surgery 137: 457-462, 2005.

MANNING MW, CASSI LA, HUANG J, SZILVASSY SJ, DAUGHERTY A: Abdominal aortic aneurysms: fresh insights from a novel animal model of the disease. Vasc Med 7: 45-54, 2002.

MARINOV GR, MAROIS Y, PARIS E, ROBY P, FORMICHI M, DOUVILLE Y, GUIDOIN R: Can the infusion of elastase in the abdominal aorta of the Yucatan miniature swine consistently produce experimental aneurysms? J Invest Surg 10: 129-150, 1997.

MATA KM, PRUDENTE PS, ROCHA FS, PRADO CM, FLORIANO EM, ELIAS J JR, RIZZI E, GERLACH RF, ROSSI MA, RAMOS SG: Combining two potential causes of metalloproteinase secretion causes abdominal aortic aneurysms in rats: a new experimental model. Int J Exp Pathol 92: 26-39, 2011.

MAYNAR M, QIAN Z, HERNANDEZ J, SUN F, DEMIGUEL C, CRISOSTOMO V, USON J, PINEDA LF, ESPINOZA CG, CASTANEDA WR: An animal model of abdominal aortic aneurysm created with peritoneal patch: technique and initial results. Cardiovasc Intervent Radiol 26: 168-176, 2003.

MOLACEK J, TRESKA V, KOBR J, CERTIK B, SKALICKY T, KUNTSCHER V, KRIZKOVA V: Optimization of the model of abdominal aortic aneurysm - experiment in an animal model. $J$ Vasc Res 46: 1-5, 2009.

MORIS D, MANTONAKIS E, AVGERINOS E, MAKRIS M, BAKOYIANNIS C, PIKOULIS E, GEORGOPOULOS S: Novel biomarkers of abdominal aortic aneurysm disease: identifying gaps and dispelling misperceptions. Biomed Res Int 2014: 925840, 2014.

MORIS D, BAKOYIANNIS C, DOUSI E, TSAKIROPOULOS P, TSIGRIS C, PERREA D, GEORGOPOULOS S: Novel protocol for creation and study of abdominal aortic aneurysm with porcine pancreatic elastase infusion in rats. Arch Hellen Med 32: 636-644, 2015.

MORIS D, THEOCHARIS S, DAVAKIS S, PATELIS N, AGROGIANNIS G, VLACHOS IS, SPARTALIS E, ATHANASIOU A, BAKOYIANNIS C, PERREA DN, GEORGOPOULOS S: Serum Calprotectin as a novel biomarker in abdominal aortic aneurysm pathogenesis and progression: preliminary data from experimental model in rats. Curr Vasc Pharmacol in press 2017. DOI: 10.2174/1570161115666170202155724.

MURPHY EH, JOHNSON ED, ARKO FR: Device-specific resistance to in vivo displacement of stent-grafts implanted with maximum iliac fixation. $J$ Endovasc Ther 14: 585-592, 2007.

NABSETH DC, MARTIN DE, ROWE MI, GOTLIEB LS, DETERLING RA JR: Enzymatic destruction of aortic elastic tissue and possible relationship to experimental atherosclerosis. J Cardiovasc Surg (Torino) 4: 11-17, 1963.

NORDON IM, HINCHLIFFE RJ, HOLT PJ, LOFTUS IM, THOMPSON MM: Review of current theories for abdominal aortic aneurysm pathogenesis. Vascular 17: 253-263, 2009.

OSBORNE-PELLEGRIN MJ, COUTARD M, POITEVIN P, MICHEL JB, LEVY BI: Induction of aneurysms in the rat by a stenosing cotton ligature around the inter-renal aorta. Int J Exp Pathol 75: 179-190, 1994. 
PATEL MI, MELROSE J, GHOSH P, APPLEBERG M: Increased synthesis of matrix metalloproteinases by aortic smooth muscle cells is implicated in the etiopathogenesis of abdominal aortic aneurysms. J Vasc Surg 24: 82-92, 1996.

PEREIRA L, ANDRIKOPOULOS K, TIAN J, LEE SY, KEENE DR, ONO R, REINHARDT DP, SAKAI LY, BIERY NJ, BUNTON T, DIETZ HC, RAMIREZ F: Targetting of the gene encoding fibrillin-1 recapitulates the vascular aspect of Marfan syndrome. Nature Genet 17: 218-222, 1997.

PEREIRA L, LEE SY, GAYRAUD B, ANDRIKOPOULOS K, SHAPIRO SD, BUNTON T, BIERY NJ, DIETZ HC, SAKAI LY, RAMIREZ F: Pathogenetic sequence for aneurysm revealed in mice underexpressing fibrillin-1. Proc Natl Acad Sci U S A 96: 3819-3823, 1999.

POWELL J: Models of arterial aneurysm: for the investigation of pathogenesis and pharmacotherapy - a review. Atherosclerosis 87: 93-102, 1991.

PYO R, LEE JK, SHIPLEY JM, CURCI JA, MAO D, ZIPORIN SJ, ENNIS TL, SHAPIRO SD, SENIOR RM, THOMPSON RW: Targeted gene disruption of matrix metalloproteinase-9 (gelatinase B) suppresses development of experimental abdominal aortic aneurysms. J Clin Invest 105: 1641-1649, 2000.

QIAN HS, GU JM, LIU P, KAUSER K, HALKS-MILLER M, VERGONA R, SULLIVAN ME, DOLE WP, DENG GG: Overexpression of PAI-1 prevents the development of abdominal aortic aneurysm in mice. Gene Ther 15: 224-232, 2008.

ROSS R, KLEBANOFF SJ: The smooth muscle cell. I. In vivo synthesis of connective tissue proteins. $J$ Cell Biol 50: 159-171, 1971.

ROWE VL, STEVENS SL, REDDICK TT, FREEMAN MB, DONNELL R, CARROLL RC, GOLDMAN MH: Vascular smooth muscle cell apoptosis in aneurysmal, occlusive, and normal human aortas. J Vasc Surg 31: 567-576, 2000.

RUSH C, NYARA M, MOXON JV, TROLLOPE A, CULLEN B, GOLLEDGE J: Whole genome expression analysis within the angiotensin II-apolipoprotein E deficient mouse model of abdominal aortic aneurysm. BMC genomics 10: 298, 2009.

SARAFF K, BABAMUSTA F, CASSIS LA, DAUGHERTY A: Aortic dissection precedes formation of aneurysms and atherosclerosis in angiotensin II-infused, apolipoprotein E-deficient mice. Arterioscler Thromb Vasc Biol 23: 1621-1626, 2003.

SCHERMERHORN ML, CRONENWETT JL: The UK small aneurysm trial. J Vasc Surg 33: 443, 2001.

SCHMOKER JD, LEE CH, TAYLOR RG, CHUNG A, TROMBLEY L, HARDIN N, RUSSELL SR, HOWARD A: A novel model of blunt thoracic aortic injury: a mechanism confirmed? J Trauma 64: 923-931, 2008.

SCHOLZ M, MUCKE T, DURING M, PECHLIVANIS I, SCHMIEDER K, HARDERS AG: Microsurgically induced aneurysm models in rats, part I: techniques and histological examination. Minim Invasive Neurosurg 51: 76-82, 2008.

SCHULTZ G, TEDESCO MM, SHO E, NISHIMURA T, SHARIF S, DU X, MYLES T, MORSER J, DALMAN RL, LEUNG LL: Enhanced abdominal aortic aneurysm formation in thrombin-activatable procarboxypeptidase Bdeficient mice. Arterioscler Thromb Vasc Biol 30: 1363-1370, 2010.

SHARMA AK, LU G, JESTER A, JOHNSTON WF, ZHAO Y, HAJZUS VA, SAADATZADEH MR, SU G, BHAMIDIPATI CM, MEHTA GS, KRON IL, LAUBACH VE, MURPHY MP, AILAWADI G, UPCHURCH GR JR: Experimental abdominal aortic aneurysm formation is mediated by IL-17 and attenuated by mesenchymal stem cell treatment. Circulation 126: S38-S45, 2012.

SHIMIZU K, MITCHELL RN, LIBBY P: Inflammation and cellular immune responses in abdominal aortic aneurysms. Arterioscler Thromb Vasc Biol 26: 987-994, 2006.

SILENCE J, COLLEN D, LIJNEN HR: Reduced atherosclerotic plaque but enhanced aneurysm formation in mice with inactivation of the tissue inhibitor of metalloproteinase-1 (TIMP-1) gene. Circulation Res 90: 897-903, 2002.

SOULEZ G, LEROUGE S, SALAZKIN I, DARSAUT T, OLIVA VL, RAYMOND J: Type I and collateral flow in experimental aneurysm models treated with stent-grafts. J Vasc Interv Radiol 18: 265-272, 2007.

SUN J, SUKHOVA GK, YANG M, WOLTERS PJ, MACFARLANE LA, LIBBY P, SUN C, ZHANG Y, LIU J, ENNIS TL, KNISPEL R, XIONG W, THOMPSON RW, BAXTER BT, SHI GP: Mast cells modulate the pathogenesis of elastase-induced abdominal aortic aneurysms in mice. J Clin Invest 117: 3359-3368, 2007. 
SVENSJO S, BJORCK M, GURTELSCHMID M, DJAVANI GIDLUND K, HELLBERG A, WANHAINEN A: Low prevalence of abdominal aortic aneurysm among 65-year-old Swedish men indicates a change in the epidemiology of the disease. Circulation 124: 1118-1123, 2011.

TANAKA A, HASEGAWA T, CHEN Z, OKITA Y, OKADA K: A novel rat model of abdominal aortic aneurysm using a combination of intraluminal elastase infusion and extraluminal calcium chloride exposure. J Vasc Surg 50: 1423-1432, 2009.

TANAKA A, HASEGAWA T, MORIMOTO K, BAO W, YU J, OKITA Y, TABATA Y, OKADA K: Controlled release of ascorbic acid from gelatin hydrogel attenuates abdominal aortic aneurysm formation in rat experimental abdominal aortic aneurysm model. J Vasc Surg 60: 749-758, 2014.

TANAKA H, ZAIMA N, SASAKI T, SANO M, YAMAMOTO N, SAITO T, INUZUKA K, HAYASAKA T, GOTO-INOUE N, SUGIURA Y, SATO K, KUGO H, MORIYAMA T, KONNO H, SETOU M, UNNO N: Hypoperfusion of the adventitial vasa vasorum develops an abdominal aortic aneurysm. PLoS One 10: e0134386, 2015.

THOMPSON RW, HOLMES DR, MERTENS RA, LIAO S, BOTNEY MD, MECHAM RP, WELGUS HG, PARKS WC: Production and localization of 92-kilodalton gelatinase in abdominal aortic aneurysms. An elastolytic metalloproteinase expressed by aneurysm-infiltrating macrophages. J Clin Invest 96: 318-326, 1995.

TROLLOPE A, MOXON JV, MORAN CS, GOLLEDGE J: Animal models of abdominal aortic aneurysm and their role in furthering management of human disease. Cardiovasc Path 20: 114-123, 2011.

TSURUDA T, KATO J, HATAKEYAMA K, KOJIMA K, YANO M, YANO Y, NAKAMURA K, NAKAMURAUCHIYAMA F, MATSUSHIMA Y, IMAMURA T, ONITSUKA T, ASADA Y, NAWA Y, ETO T, KITAMURA K: Adventitial mast cells contribute to pathogenesis in the progression of abdominal aortic aneurysm. Circulation Res 102: 1368-1377, 2008.

USON-GARGALLO J, CRISOSTOMO V, LOSCERTALES B, SUN F, SANCHEZ-MARGALLO FM, MARTINCANCHO MF, MAYNAR M: A new model of abdominal aortic aneurysm with gastric serosa patch: surgical technique and short-term evaluation. J Invest Surg 19: 97-104, 2006.

XIONG W, KNISPEL RA, DIETZ HC, RAMIREZ F, BAXTER BT: Doxycycline delays aneurysm rupture in a mouse model of Marfan syndrome. J Vasc Surg 47: 166-172, 2008.

YAMAGUCHI T, YOKOKAWA M, SUZUKI M, HIGASHIDE S, KATOH Y, SUGIYAMA S, MISAKI T: The time course of elastin fiber degeneration in a rat aneurysm model. Surgery Today 30: 727-731, 2000.

YAMAGUCHI T, YOKOKAWA M, SUZUKI M, HIGASHIDE S, KATOH Y, SUGIYAMA S, MISAKI T: Morphologic changes in the aorta during elastase infusion in the rat aneurysm model. J Surg Res 95: 161-166, 2001.

ZHANG J, SCHMIDT J, RYSCHICH E, SCHUMACHER H, ALLENBERG JR: Increased apoptosis and decreased density of medial smooth muscle cells in human abdominal aortic aneurysms. Chin Med J 116: 1549-1552, 2003.

ZHOU HF, YAN H, CANNON JL, SPRINGER LE, GREEN JM, PHAM CT: CD43-mediated IFN-gamma production by CD8+ T cells promotes abdominal aortic aneurysm in mice. J Immunol 190: 5078-5085, 2013. 